\title{
Sistem Informasi Keluhan Pelanggan Pada Perusahaan Daerah Air Minum (PDAM) Kabupaten Lombok Tengah
}

\author{
Rohana1, Khairul Imtihan² \\ 1Teknik Informatika, STMIK Lombok \\ ${ }^{2}$ Sistem Informasi, STMIK Lombok \\ Jln. Basuki Rahmat No.105 Praya Lombok Tengah 83511 \\ 1 tryrohana@gmail.com, ${ }^{2}$ khairulimtihan31@gmail.com
}

\begin{abstract}
The development of information technology increasingly faster, one of the advantages obtained is the easier people in communicating, sending information, or get information. This needs improved performance in terms of effectiveness and efficiency of service providers (Sukmana, 2014).

Perusahaan Daerah Air Minum (PDAM) Lombok Tengah in the service of customer complaints whether it be leak pipe complaints, meter replacement, inappropriate water usage and water is often jammed, Officer will check customer data on customer information then record customer's complaint and save on book complaint customer. After conducting data collection on the complaint, the officer in the subscriber hubungan langganan (HUBLANG) will make the warrant to be submitted to the transmisi dan distribusi (TRANSDIT) to make improvements made by the maintenance department, because the complaint process is still recorded in the customer complaint book allowing the complaint data is lost or scattered so it can hinder the process of repair or maintenance, so that required a system that can process and store customer complaints data.

The method of designing customer complaint information system at Perusahaan Daerah Air Minum (PDAM) Lombok Tengah uses SDLC (Systems Development Life Cycle) method with planning, analysis, design, implementation and testing phase. In the planning phase, data collecting using obsevation method, interview and literature study are used in the analysis phase using SWOT method (strengths, weaknesses, opportunities, threats), at design stage, the system design will be proposed using DFD (Data Flow Digram) starting from diagram Context of Customer Complaints Information System and DFD Level 1 Customer Complaints Information System, followed by table design, design of ERD (entity relationship diagram), design of menu structure and design of system interfaces, in the implementation phase of the system made system in accordance with the design phase using php programming language with the mysql database while in the testing phase using the method of balck box system, the results of the design will be easier for customers in the process of complaint submission without having to come again to the PDAM Kabupaten Lombok Tengah and can facilitate the subscriber hubungan langganan (HUBLANG) in recording customer data that conduct customer complaints process.
\end{abstract}

Keywords : Complaints Information System, PDAM, SDLC.

\begin{abstract}
Abstrak
Perkembangan teknologi informasi semakin lama semakin cepat, salah satu keuntungan yang didapatkan adalah semakin mudahnya orang dalam berkomunikasi, mengirim informasi, atau mendapatkan informasi. Hal ini perlu adanya peningkatan kinerja baik dari segi efektifitas dan efisiensi dari penyedia layanan (Sukmana, 2014).

Perusahaan Daerah Air Minum (PDAM) Lombok Tengah dalam pelayanan keluhan pelanggan baik itu keluhan pipa bocor, penggantian meter, pembayaran air yang tidak sesuai pemakaian dan air sering macet, Petugas akan memeriksa data pelanggan pada informasi pelanggan kemudian mencatat keluhan pelanggan dan meyimpan pada buku keluhan pelanggan. Setelah melakukan pendataan terhadap keluhan maka petugas dibagian hubungan langganan (HUBLANG) akan membuatkan surat perintah yang akan diserahkan kebagian transmisi dan distribusi (TRANSDIT) untuk melakukan perbaikan yang dilakukan oleh bagian perawatan, karna proses pengajuan keluhan itu masih dicatat didalam buku keluhan pelanggan memungkinkan data keluhan tersebut hilang atau tercecer sehingga dapat menghambat proses
\end{abstract}


perbaikan atau perawatan, sehingga diperlukan sebuah sistem yang dapat mengolah dan menyimpan data keluhan pelanggan.

Metode perancangan sistem informasi keluhan pelanggan pada Perusahaan Daerah Air Minum (PDAM) Lombok Tengah menggunkaan metode SDLC (Systems Development Life Cycle) dengan tahapan perencanaan, analisis, perancangan, implementasi dan pengujian. Pada tahap perencanaan dilakukan pengumpulan data dengan metode obsevasi, wawancara dan studi pustaka, pada tahap analisis menggunkan metode SWOT (strengths, weaknesses, opportunities, threats), pada tahap perancangan dilakukan perancangan sistem yang akan diusulkan menggunakan DFD (Data Flow Digram) mulai dari Diagram Konteks Sistem Informasi Keluhan Pelanggan dan DFD Level 1 Sistem Informasi Keluhan Pelanggan, dilanjutkan dengan perancangan tabel, perancangan ERD (entity relationship diagram), perancangan struktur menu dan perancangan interface sistem, pada tahap implementasi sistem dilakukan pembuatan sistem sesuai dengan tahap perancangan menggunkan bahasa pemrograman php dengan database mysql sedangkan pada tahap pengujian menggunakan metode balck box sistem, dari hasil perancangan tersebut nantinya dapat mempermudah pelanggan dalam melakukan proses penyampaian keluhan tanpa harus datang lagi ke kantor PDAM Kabupaten Lombok Tengah dan dapat mempermudah bagian hubungan langganan (HUBLANG) dalam merekap data-data pelanggan yang melakukan proses keluhan pelanggan.

Kata kunci : Sistem Informasi Keluhan, PDAM, SDLC. 


\section{Pendahuluan}

Perkembangan teknologi informasi semakin lama semakin cepat, salah satu keuntungan yang didapatkan adalah semakin mudahnya orang dalam berkomunikasi, mengirim informasi, atau mendapatkan informasi. Hal ini perlu adanya peningkatan kinerja baik dari segi efektifitas dan efisiensi dari penyedia layanan (Sukmana, 2014).

Perusahaan Daerah Air Minum (PDAM) Lombok Tengah dalam pelayanan keluhan pelanggan baik itu keluhan pipa bocor, penggantian meter, pembayaran air yang tidak sesuai pemakaian dan air sering macet, Petugas akan memeriksa data pelanggan pada informasi pelanggan kemudian mencatat keluhan pelanggan dan meyimpan pada buku keluhan pelanggan. Setelah melakukan pendataan terhadap keluhan maka petugas dibagian hubungan langganan (HUBLANG) akan membuatkan surat perintah yang akan diserahkan kebagian transmisi dan distribusi (TRANSDIT) untuk melakukan perbaikan yang dilakukan oleh bagian perawatan, karna proses pengajuan keluhan itu masih dicatat didalam buku keluhan pelanggan memungkinkan data keluhan tersebut hilang atau tercecer sehingga dapat menghambat proses perbaikan atau perawatan, sehingga diperlukan sebuah sistem yang dapat mengolah dan menyimpan data keluhan pelanggan.

Sistem informasi keluhan pelanggan yang diusulkan dapat mempermudah pelanggan dalam melakukan proses penyampaian keluhan tanpa harus datang lagi ke kantor PDAM Kabupaten Lombok Tengah dan dapat mempermudah bagian hubungan langganan (HUBLANG) dalam merekap data-data pelanggan yang melakukan proses keluhan pelanggan.

\section{Tinjuan Pustaka}

Fajarita, dkk (2015), dalam penelitiannya Analisa Perancangan Sistem Informasi Penanganan Keluhan Pada PT Paron Indonesia, penelitian tersebut bertujuan menangani keluhan dari pelanggan jika terdapat masalah pada produk yang sudah dibeli. Dalam hal ini, produk yang bermasalah akan dikembalikan dan diganti berdasarkan dengan ketentuan yang berlaku. Proses pencatatan data keluhan dari pelanggan dan proses penggantian barang masih bersifat manual, sehingga palayanan terhadap pelanggan pun dirasa kurang maksimal. Oleh sebab itu untuk mencatat dan mengorganisir proses tersebut, maka dibutuhkan sebuah sistem informasi yang menunjang sehingga dapat meningkatkan produktivitas kerja yang lebih efektif dan efesien. Berdasarkan kebutuhan saat ini, sistem informasi tersebut akan dibuat dalam versi desktop dengan menggunakan Microsoft Visual Studio 2008 dan database MySql.

Hulaliyah (2014), dalam penelitiannya Analisa Sistem Informasi Pelayanan Pelanggan Berbasis Web Pada PDAM Cabang Teluk Naga Tangerang. Permasalahan yang terjadi pada perusahaan belum memiliki website dan sering kali kosumen mengalami kesulitan dalam hal konsultasi, mencari lokasi perusahaan dan melihat gambar dari contoh-contoh produk yang mereka inginkan. Beberapa permasalahan juga banyak ditemui khususnya dalam mempromosikan produk, dimana pada awalnya mereka menggunakan media cetak dan telepon seperti iklan koran, brosur dan menghubungi konsumen sebagai pilihan dalam mempublikasikan dan mempromosikan produk mereka, itu semua dirasa kurang efisien dari segi waktu dan biaya, sehingga banyak dari calon pelanggan pengunjung atau pelanggan tidak perlu datang langsung untuk mendapatkan informasi yang dibutuhkan dan untuk bertransaksi memesan produk yang ingin dibeli atau untuk mengetahui harga-harga dan kualitas produk.

Kusuma (2014), dalam penelitiannya Pembuatan Website Monitoring Keluhan Pelanggan (Studi Kasus Pada PT Telkom Unit Layanan Ngadirojo ). Faktor yang mempengaruhi penurunan pelanggan berasal dari masalah pelayanan dari pihak Telkom dalam menangani masalah keluhan dari para pelanggan Telkom yaitu cara Telkom dalam menerima data keluhan dari pelanggan selama ini masih menggunakan media telepon, kemudian data yang masuk hanya ditulis pada kertas dan tidak disimpan dalam database. Dengan demikian jika data-data keluhan yang telah masuk diperlukan lagi pada saat tertentu maka akan sulit dalam pencariannya

\section{Metodologi Penelitian}

\subsection{Metode Pengumpulan Data}

1. Observasi

Mengadakan pengamatan secara langsung pada bagian hubungan langganan PDAM Lombok Tengah dengan mencatat hal yang dianggap penting untuk mendapatkan informasi keluhan pelanggan, dengan mengamati administrasi pelaporan, proses keluhan, dan proses pelaporan. 


\section{Wawancara}

Melakukan tanya jawab dengan pihak PDAM pada bagian hubungan langganan (HUBLANG).

3. Studi Pustaka

Mempelajari teori-teori baik dari buku-buku, jurnal dan internet yang berhubungan dengan tema penelitian.

\subsection{Metode Analisis}

Metode analisis yang digunakan dalam penelitian ini adalah metode SWOT dengan menganalisa kekuatan, kelemahan, peluang, dan ancaman sistem yang sedang berjalan.

\subsection{Metode Perancangan}

Metode perancangan yang digunakan adalah metode SDLC (Systems Development Life Cycle) dengan tahapan-tahaan perencanaan, analisa, desain, implementasi, pengujian dan pemeliharaan

\subsection{Metode Pengujian Sistem}

Metode testing yang digunakan adalah metode black box dengan menguji prosedur perancangan yang terdiri dari input, proses, dan output sistem informasi keluhan pelanggan pada PDAM Lombok Tengah.

\section{Hasil dan Pembahasan}

\subsection{Flowmap Sistem}

\subsubsection{Flowmap Sistem Berjalan}

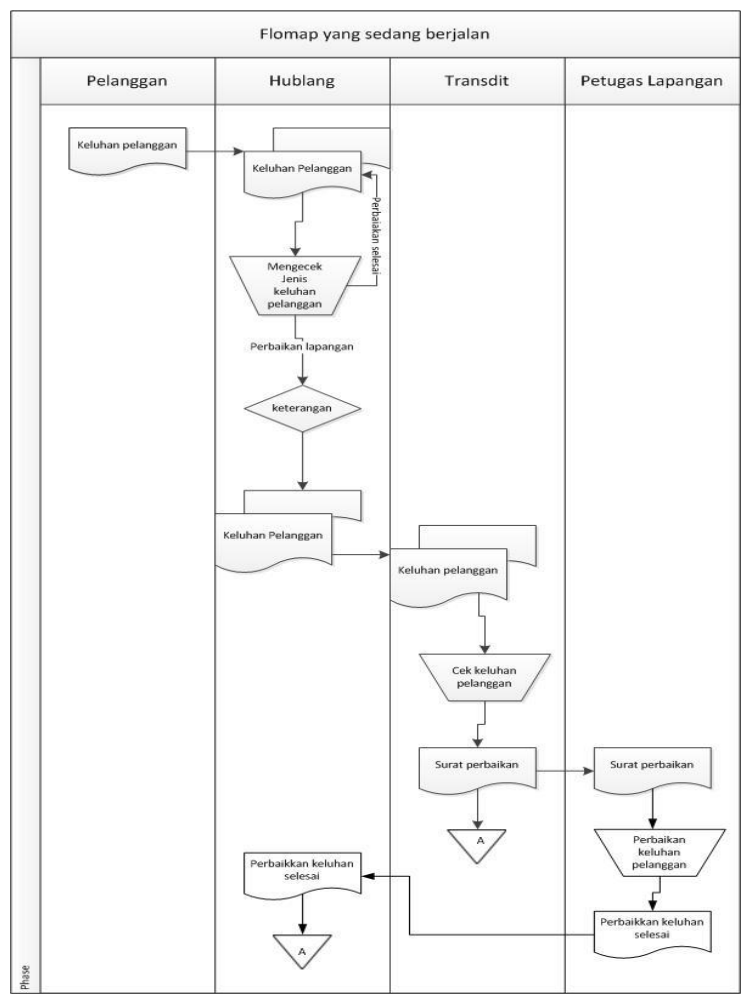

Gambar 4.1 Flowmap Sistem Berjalan
Keterangan Gambar :

1. Pelanggan melaporkan keluhan ke kantor PDAM Lombok Tengah dengan membawa bukti keluhan.

2. Petugas dibagian hubungan langganan mencatat keluhan pelanggan dan mengecek apa permasalahan keluhan pelanggan. Jika masalah rekening pembayaran bisa diselesaikan dibagian hubungan langganan sedangkan keluhan pelanggan yang ada dilapangan akan diserahkan kebagian transmisi dan distribusi.

3. Bagian transmisi dan distribusi mengecek bahan-bahan yang dibutuhkan dalam melakukan perbaikan keluhan pelanggan yang akan diserahkan kepada petugas lapangan, kemudian petugas mengarsipkan data pengeluaran bahan-bahan perbaikan

4. Petugas lapangan bertugas memperbaiki keluhan pelanggan

5. Petugas lapangan melaporkan hasil perbaikkan keluhan pelanggan kepada bagian hubungan langganan.

6. Bagian hublang mengarsipkan data-data hasil perbikkan keluhan pelanggan pada buku besar.

\subsubsection{Flowmap Usulan}

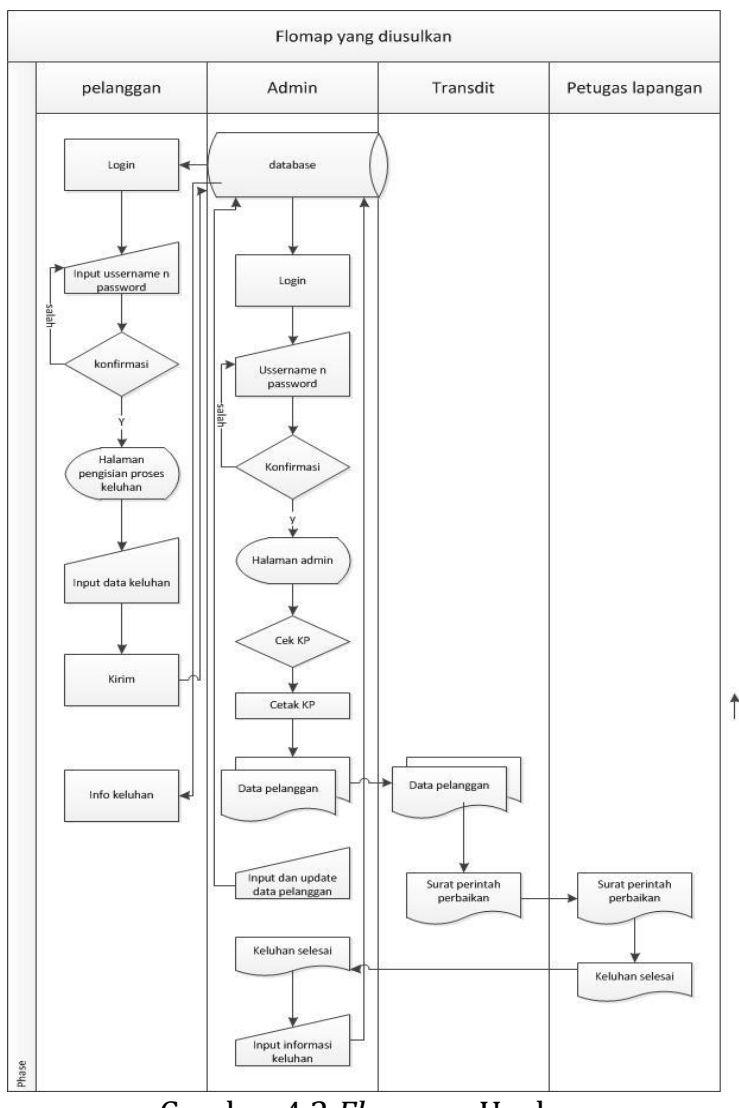

Gambar 4.2 Flowmap Usulan 
Keterangan Gambar :

1. Pelanggan terlebih dahulu melakuan proses login dengan memasukkan username dan password, jika username dan password benar maka pelanggan berhasil masuk kesistem. Kemudian pelanggan melakukan peginputan data keluhan pelanggan.

2. Petugas bagian hubungan (admin) langganan akan mengecek keluhan pelanggan disistem tetapi pelanggan harus login terlebih dahulu dengan mengimputkan username dan password. Jika username dan password benar maka admin berhasil masuk ke sistem dan mulai mengecek data pelanggan yang melakukan keluhan jika masalah perbaikan rekening air bisa diselesaikan dibagian hubungan langganan sedangkan masalah keluhan pelanggan dilapangan harus dikerjakan oleh bagian petugas lapangan. Jika perbaikan sudah selesai maka admin akan mengimputkan informasi perbaikan keluhan pelanggan dan dikirim ke sistem.

3. Petugas bagian transdit mengecek laporan perbaikan keluhan pelanggan yang diserahkan pihak admin (petugas hubungan langganan) dan membuat surat perintah perbaikan keluhan pelanggan.

4. Petugas lapangan melakukan proses perbaikan keluhan pelanggan, jika keluhan pelanggan sudah selesai maka petugas lapangan melaporkan perbikan kepada bagian hubungan langganan.

\subsection{Perancangan Proses}

\subsubsection{DFD (Data Flow Diagram)}

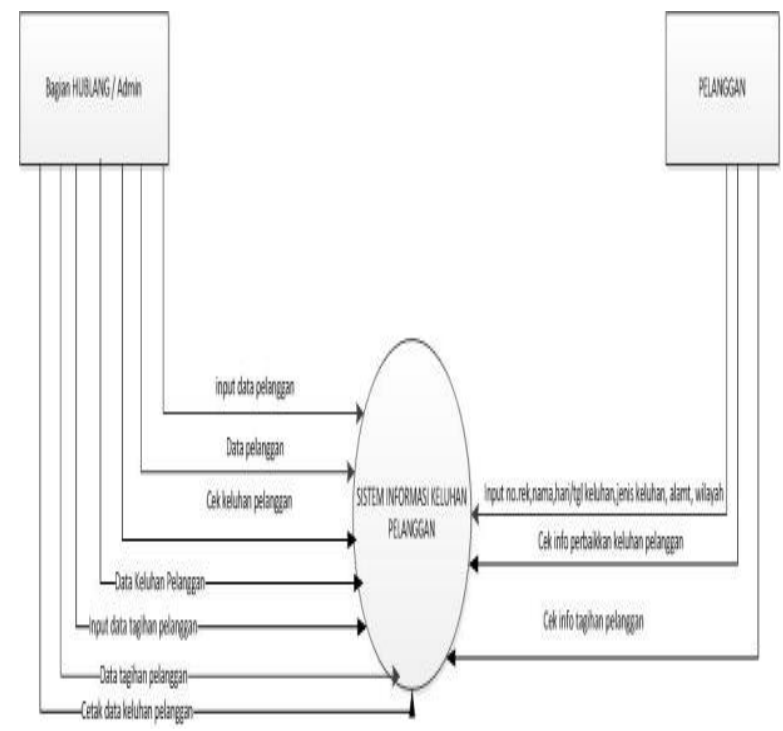

Gambar 4.3 Diagram Konteks Sistem Informasi Keluhan Pelanggan

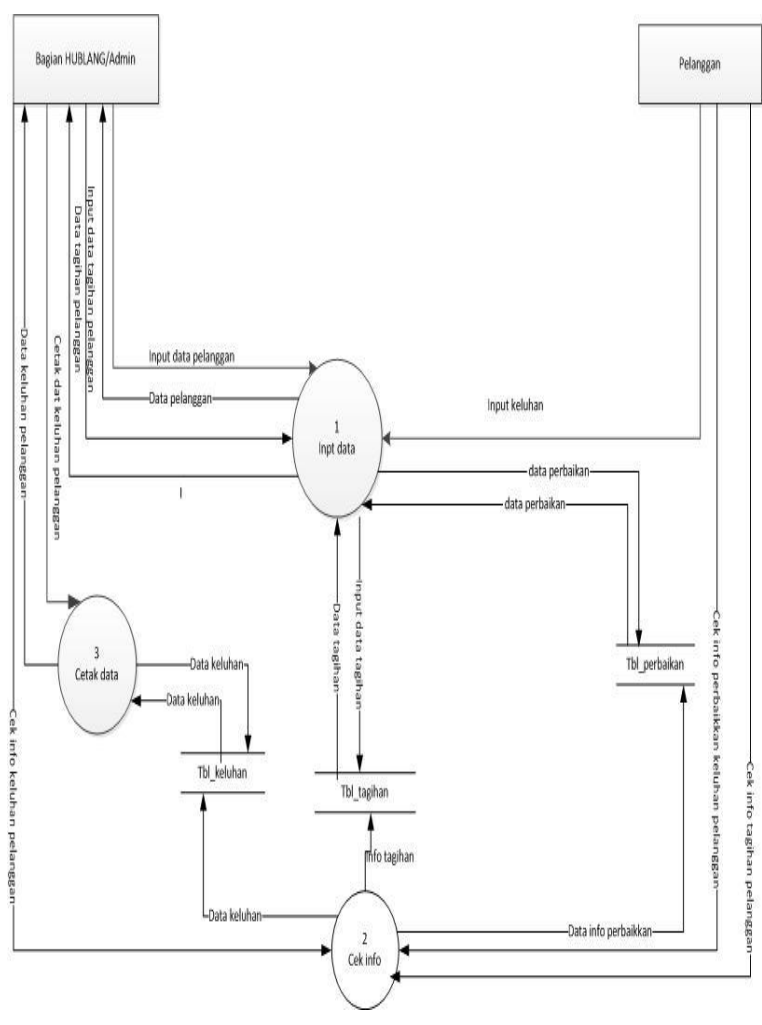

Gambar 4.4 DFD Level 1 Sistem Informasi Keluhan Pelanggan

Keterangan Gambar :

Sistem terdiri dari tiga proses yaitu proses login, input data, dan cetak data. Bagian admin dan pelanggan melakukan proses login dengan menginputkan username dan password, jika username dan password salah maka sistem memberikan konvirmasi. Kemudian pelanggan melakukan proses penginputan data keluhan dan upload bukti pembayaran rekening air jika pelanggan yang akan melakukan proses keluhan pembayaran yang tidak sesuai dengan pemakaian, sedangkan admin pada proses penginputan data dapat melakukan input data pelanggan, dan update data pelanggan, dan menginput informasi keluhan pelanggan apakah keluhan pelanggan sudah diperbaiki atau belum. Pada proses cetak data admin dapat mencetak data keluhan pelanggan dan download bukti rekening keluhan pelanggan. Petugas lapangan melakuan pengimputan data perbaikan keluhan pelanggan. 


\subsubsection{Perancangan ERD (Entity Relationship Diagram)}

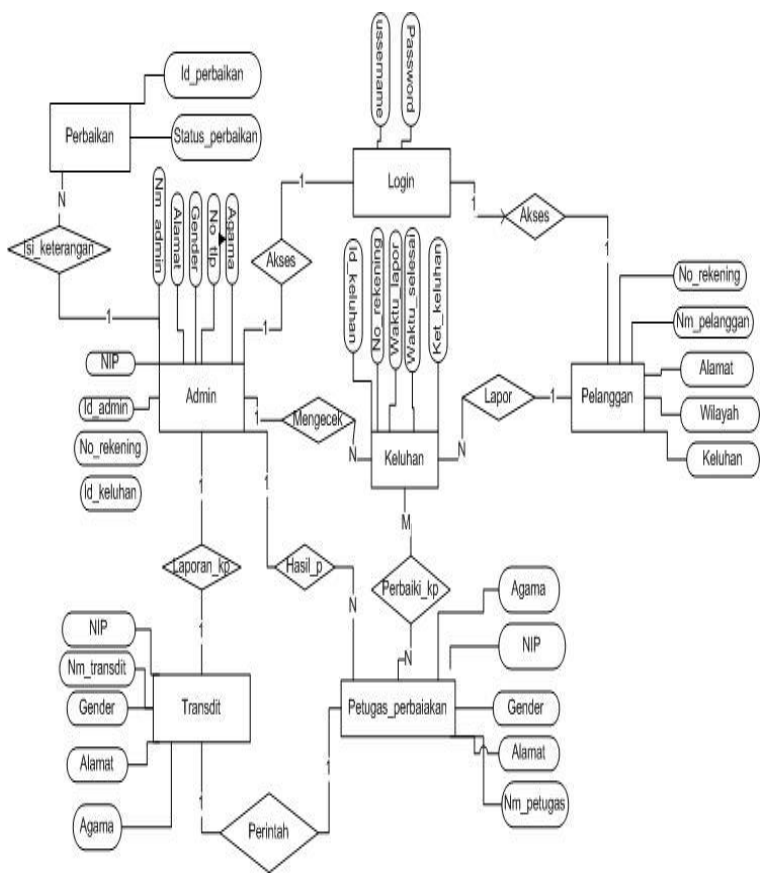

Gambar 4.5 ERD (Entity Relationship Diagram)

\subsection{Perancangan Interface}

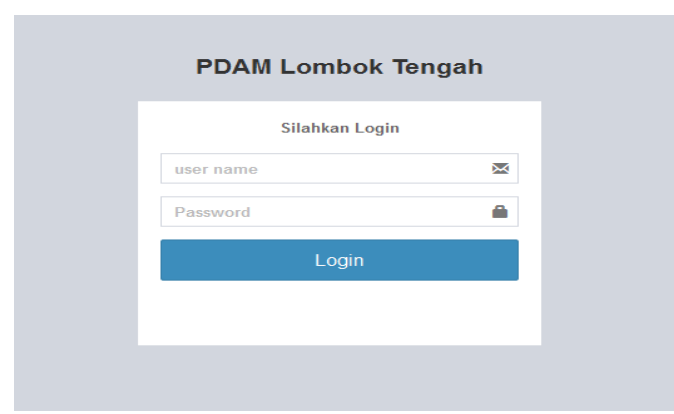

Gambar 4.6 Halaman Login

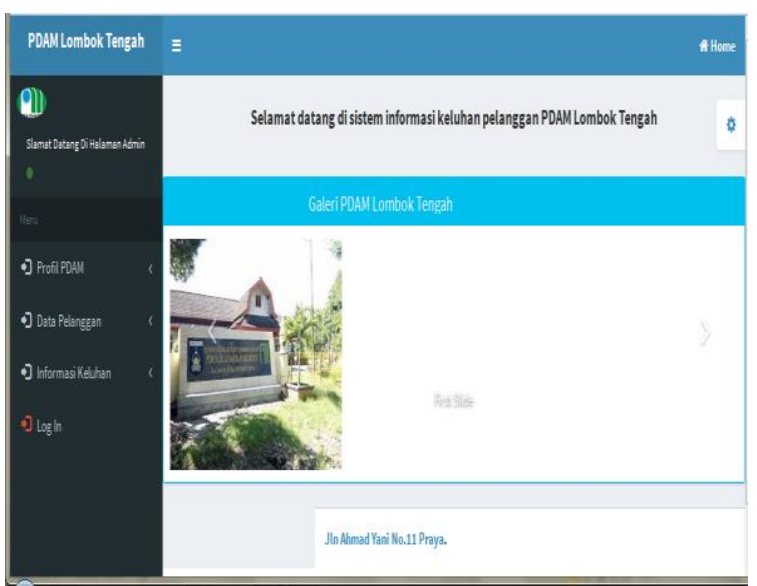

Gambar 4.7 Halaman Utama
Sebelum pelanggan dan admin melakukan proses pada menu-menu sisfo_keluhan pelanggan dan admin harus melakukan proses login terlebih dahulu dengan menginputkan username dan password jika password dan username salah maka pelanggan dan admin tidak berhasil login

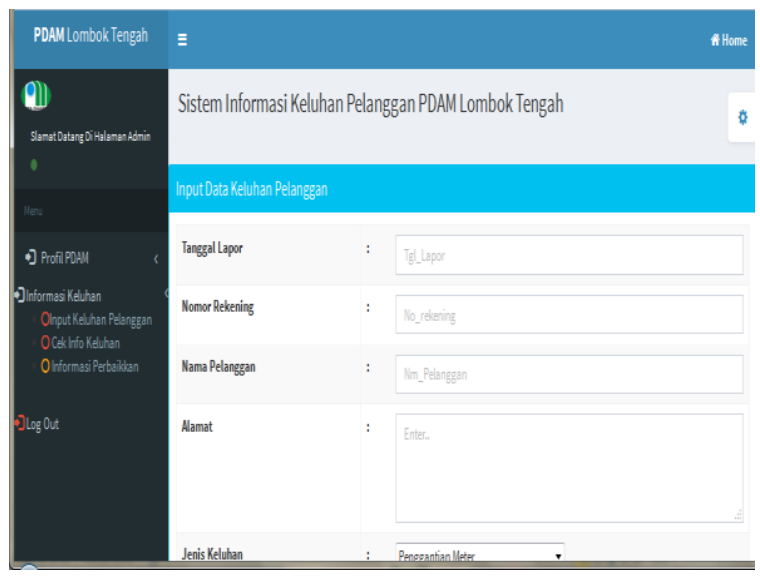

Gambar 4.8 Halaman Input Keluhan Pelanggan

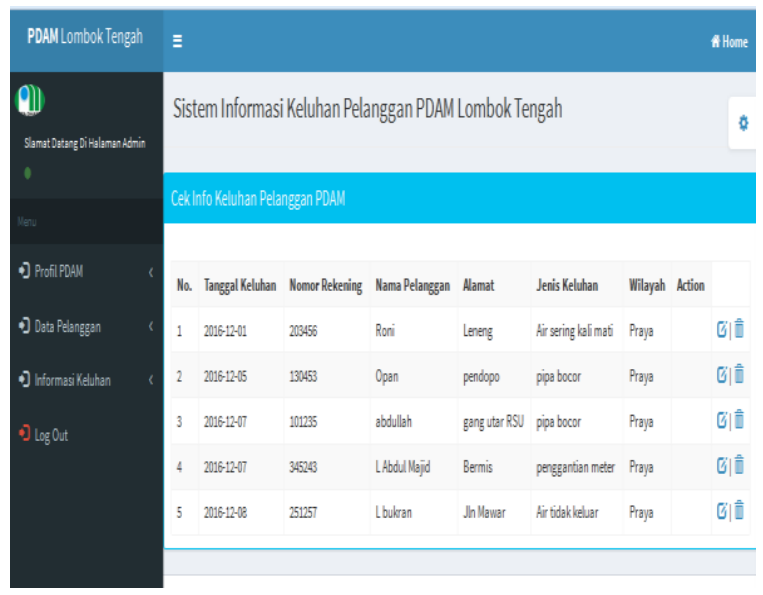

Gambar 4.9 Halaman Info Keluhan Pelanggan

Keterangan Gambar :

Pada menu cek keluhan pelanggan terdapat data-data pelanggan yang melakukan proses keluhan pelanggan. Data keluhan pelanggan dapat diakses oleh admin.

\section{Kesimpulan dan saran}

\subsection{Kesimpulan}

Dari hasil analisis, perancangan sistem serta pembuatan sistem informasi keluhan pelanggan pada Perusahaan Daerah Air Minum (PDAM) Kabupaten Lombok Tengah yang telah diuraikan pada bab sebelumnya, maka dapat diambil beberapa kesimpulan sebagai berikut: 
Dengan adanya sistem informasi keluhan pelanggan dapat mempermudah pelanggan dalam melakukan proses penyampaian keluhan tanpa harus datang lagi ke kantor PDAM Kabupaten Lombok Tengah dan dapat mempermudah bagian hubungan langganan (HUBLANG) dalam merekap data-data pelanggan yang melakukan proses keluhan secara terkomputerisasi.

\subsection{Saran}

1. Sistem informasi keluhan pelanggan disarankan supaya selalu diupdate sesuai dengan perkembangan yang ada, termasuk penambahan fasilitas dan fitur sesuai dengan kebutuhan yang ada.

2. Untuk mempermudah pelanggan dalam memperoleh informasi yang lebih akurat, untuk pengembangan selanjutnya dapat menggunakan sms gatway.

\section{Daftar Pustaka:}

\section{Pustaka Buku}

Abdulloh, Rohi, (2015). Web Programming Is Easy. Jakarta: Gramedia

Adi Nugroho, (2011). Perancanga Dan Implementasi Sistem Basis Data. Yogyakarta: Andi

Hanif Al Fatta, (2007). Analisi Dan Perancangan Informasi Untuk Keunggulan Bersaing Perusahaan Dan Organisasi Modern. Yogyakarta : Andi

Kadir, Abdul, (2009). Dasar perancangan \& implementasi Database Relasional. Yogyakarta : Andi

Kadir, Abdul, (2009).Pengenalan Sistem Informasi Jakarta : Andi

Komputer, Wahana. 2006. Panduan Praktis Pengolahan Database dengan MySQL. Yogyakarta: Andi

Madcoms, (2011). Aplikasi Web Database Dengan Dreamweaver dan PHP MySQL. Yogyakarta : Andi

Peranginangin, Kasiman (2006) Aplikasi WEB dengan PHP dan MySQL.Yogyakarta: Andi

Presman, S. Roger, (2010). Rekayasa Peranggkat Lunak-buku, Pendekatan Praktisi (Edisi 7). Yogyakarta : Andi

Siagian ,p.sondang (2002) System Informasi Manajemen Yogyakarta : Andi
Yakub, (2012). Pengantar Sistem Informasi. Yogyakarta: Andi

Pustaka Majalah, Jurnal Ilmiah atau Prosiding

Anggi Bingar Kusuma, Lies Yulianto (2014) Pembuatan Website Monitoring Keluhan Pelanggan Pada PT Telkom Unit Layanan Ngadirojo. Jurnal Networking And Scurity vol.3

Hendra Gunawan, Irwan Agustin (2014) Aplikasi Pelayanan Gangguan Listrik Berbasis Web Di Rayon Banjaran. Jurnal Informasi vol .6

Hulaliyah, Ahmad (2014) Analisa Sistem Informasi Pelayanan Pelanggan Berbasis Web Pada PDAM Cabang Teluk Naga Tangerang.Akademi Manajemen Informatika. Vol.1

Mudjahidin (2011) Pembuatan Sistem Informasi Manajemen Keluhan pelanggan Berbasis Web Dan Sms. Jurnal Sistem Informasi vol.4

Sukmana, Roby (2014) Perancangan Sistem Informasi Pengajuan Tugas Akhir Online Menggunakan Php Dan Msql. Jurnal Teknik Informatika. Vol.1

Lombok, S. T. M. I. K., and Ahmad Susan Pardiansyah. "Audit Tata Kelola Teknologi Informasi Program Studi Sistem Informasi Sekolah Tinggi Manajemen Informatika Dan Komputer (STMIK) Lombok Menggunakan." IJSE-Indonesian Journal on Software Engineering 1.1 (2015).

Lombok, Maulana Ashari-STMIK. "Audit Information Technology (IT) Governance Pada Sekolah Tinggi Manajemen Informatika Dan Komputer (STMIK) Lombok Menggunakan Framework COBIT 4.1." Bianglala Informatika 3.2 (2015).

Lombok, Hairul Fahmi-STMIK. "Efektifitas Wireless Lan Berbasis 802.11 b/g Sebagai Solusi Jaringan Kampus (Studi Kasus: Sekolah Tinggi Agama Hindu (STAHN) Gde Pudja Mataram." IJNS-Indonesian Journal on Networking and Security 4.4 (2015). 